\title{
Histopathological evaluation of Senecio rhizomatus Rusby in 7,12-dimethylbenz $(\alpha)$ anthracene-induced breast cancer in female rats
}

\author{
Jorge Luis Arroyo-Acevedo1(D), Oscar Herrera-Calderon² (D), Juan Pedro Rojas-Armas ${ }^{1}$ (D), Roberto Chávez-Asmat ${ }^{3}$ (D) \\ James Calva ${ }^{4}$ and Tapan Behl ${ }^{5}$ (D)
}

\begin{abstract}
1. Laboratory of Experimental Pharmacology, Faculty of Medicine, Universidad Nacional Mayor de San Marcos, Av. Miguel Grau 755, Cercado de Lima 15001, Peru; 2. Department of Pharmacology, Bromatology and Toxicology, Faculty of Pharmacy and Biochemistry, Universidad Nacional Mayor de San Marcos, Jr Puno 1002, Lima 15001, Peru; 3. Association for the Development of Student Research in Health Sciences, Faculty of Medicine. Universidad Nacional Mayor de San Marcos, Av. Miguel Grau 755, Cercado de Lima 15001, Peru; 4. Departamento de Química y Ciencias Exactas, Universidad Técnica Particular de Loja, San Cayetano s/n, 1101608 Loja, Ecuador; 5. Department of Pharmacology, Chitkara College of Pharmacy, Chitkara University, Punjab 140401, India.

Corresponding author: Oscar Herrera-Calderon, e-mail: oherreraca@unmsm.edu.pe

Co-authors: JLA: jlarroyoa@gmail.com,JPR: jprojasarmas@yahoo.com, RC: rjasmat7@gmail.com,

JC: jwcalva@utpl.edu.ec, TB: tapanbehl31@gmail.com

Received: 08-10-2020, Accepted: 25-01-2021, Published online: 06-03-2021
\end{abstract}

doi: www.doi.org/10.14202/vetworld.2021.569-577 How to cite this article: Arroyo-Acevedo JL, Herrera-Calderon O, Rojas-Armas JP, Chávez-Asmat R, Calva J, Behl T (2021) Histopathological evaluation of Senecio rhizomatus Rusby in 7,12-dimethylbenz $(\alpha)$ anthracene-induced breast cancer in female rats, Veterinary World, 14(3): 569-577.

\begin{abstract}
Background and Aim: Senecio rhizomatus Rusby (SrR) is a medicinal plant of the Asteraceae family and traditionally consumed as infusion in the Andean region from Peru for inflammatory disorders. This study aimed to determine the histopathological changes afforded by SrR in 7, 12-dimethylbenz[ $\alpha]$ anthracene (DMBA)-induced breast cancer (BC) in rats.

Materials and Methods: An ethanolic extract of SrR aerial parts was prepared by maceration with $96 \%$ ethanol, and the chemical components were identified by gas chromatography coupled to mass spectrometry; the antioxidant activity was determined by 1,1-diphenyl-2-picril-hidrazil (DPPH) assay; and the acute toxicity was assessed according to the OCED 423 guidelines. In a pharmacological study, 30 female Holztman rats were distributed randomly into five groups, as follows. Group I: Negative control (physiological serum, $2 \mathrm{~mL} / \mathrm{kg}$ ); Group II. DMBA ( $80 \mathrm{mg} / \mathrm{Kg}$ body weight); and Groups III, IV, and V: DMBA + ethanol extract of SrR at doses of 10, 100, and $200 \mathrm{mg} / \mathrm{kg}$, respectively.
\end{abstract}

Results: The antioxidant activity of the SrR extract against DPPH was $92.50 \%$ at $200 \mu \mathrm{g} / \mathrm{mL}$. The oral administration of SrR at doses of $50,300,2000$, and $5000 \mathrm{mg} / \mathrm{kg}$ did not show any clinical evidence of toxicity or occurrence of death. The groups that received SrR presented a lower frequency of tumors and acumulative tumor volume compared with the DMBA group $(\mathrm{p}<0.05)$; the DMBA group exhibited a higher incidence of necrosis and moderate mitosis, up to $66.67 \%$ and $100.00 \%$, respectively. Finally, infiltrating carcinoma with extensive tumor necrosis was evidenced.

Conclusion: In experimental conditions, the ethanolic extract of SrR had a protective effect in DMBA-induced BC in female rats. Furthermore, the antioxidant activity of its main phytochemicals could be responsible for the effect observed, and SrR seems to be a safe extract in the preclinical phase.

Keywords: breast cancer, carcinogenic, experimental pharmacology, phytotherapy, Senecio rhizomatus.

\section{Introduction}

Epidemiological studies of cancer revealed that breast cancer (BC) has a high prevalence in women and, together with lung and colorectal cancer, contributes to more than $50 \%$ of all cases of cancer. BC represents $30 \%$ of the rate of all new cancer diagnoses, thus being the type of cancer in women and being the second most common main cause of death [1]. In Peru, $\mathrm{BC}$ is the second most frequent neoplasm, which has a great economic impact, and has a poor survival rate

Copyright: Arroyo-Acevedo, et al. Open Access. This article is distributed under the terms of the Creative Commons Attribution 4.0 International License (http://creativecommons.org/licenses/ by/4.0/), which permits unrestricted use, distribution, and reproduction in any medium, provided you give appropriate credit to the original author(s) and the source, provide a link to the Creative Commons license, and indicate if changes were made. The Creative Commons Public Domain Dedication waiver (http:// creativecommons.org/publicdomain/zero/1.0/) applies to the data made available in this article, unless otherwise stated. because of its late diagnosis; thus, the establishment of a comprehensive plan that implements strategies for early diagnosis and timely medical treatment of positive cases is necessary to reduce mortality [2].

Alternative and Complementary Medicine (ACM) is part of the folk tradition in several countries and its effectiveness in medical practice is scientifically proven; thus, ACM is rising worldwide. The World Health Organization recommends the incorporation of ACM into national health systems $[3,4]$. In Peru, a complementary medicine service was implemented in EsSalud (a social health insurance) in 1998 and offered a wide variety of alternative complementary therapies, such as herbal therapy [5].

In Northern Peru, 47 species of plants, mostly Asteraceae, followed by Gentianaceae [6,7], are traditionally used to manage cancerous conditions. In the American continent, Asteraceae is the richest 
family in species in the Southern region (15\%), North America (14\%), and Mexico (13\%). Moreover, it is the second most diverse plant family in most of the Andean and Central American tropical countries [8]. After the publication of the catalog of flowering plants and gymnosperms, 222 genera and 1432 Asteraceae species were registered in Peru; subsequently, the registry was updated to 245 genera and 1530 species, with 14 genera being endemic, that is, Ascidiogyne, Caxamarca, Ellenbergia, Holoschkuhria, Hughesia, Nothobaccharis, Uleophytum, Syncretocarpus, Bishopanthus, Chionopappus, Pseudonoseris, Chucoa, Schizotrichia, and Aynia [9]. In Lima, the capital of Peru, about 385 species are known, 343 of which correspond to native and/or naturalized species and 42 are exclusively from crops, with the predominant families being Senecioneae, Heliantheae, Asteraceae, and Inuleae [10,11].

The Asteraceae family comprises species such as Senecio rhizomatus Rusby (SrR; Known as Llankahuasi), Bidens pilosa L., and Chuquiraga spinosa Lessing. The previous studies have indicated that the methanolic fraction of $B$. pilosa stopped the progression of 7, 12-dimethylbenz $[\alpha]$ anthracene (DMBA)-induced BC in rats [12]; moreover, C. spinosa also exerted a protective effect against DMBAinduced $\mathrm{BC}$ in rats because of its anti-tumorigenic, hypolipidemic, hypoglycemic, antioxidant, and antigenotoxic properties [13].

$\mathrm{BC}$ is pathology with a high frequency in women; thus, it is necessary to continue seeking therapeutic alternatives, such as natural products. Thus, the availability of previous studies of plants in the same family may lead to the exploration of their probable effects as antitumor agents. Therefore, the aims of this study were to (1) determine the protective effect of the ethanolic extract of the aerial parts of SrR in DMBAinduced $\mathrm{BC}$ in rats; (2) identify its main chemical components using gas chromatography coupled to mass spectrometry GC-MS; (3) determine its in vitro antioxidant activity against the 1,1-diphenyl-2-picril-hidrazil (DPPH) radical; (4) to assess its acute toxicity at a single dose according to the Organization for Economic Cooperation and Development (OECD) 420 guidelines; and (5) perform a histopathological study after the administration of SrR to female Holtzman rats.

\section{Materials and Methods}

\section{Ethical approval}

This research was approved by the Ethics Committee at the Faculty of Medicine of the Universidad Nacional Mayor de San Marcos, ID N ${ }^{\circ}$ 0310 (November 4, 2018). During the study, the specifications proposed by guidelines for the welfare and use of animals in cancer research were followed [14].

\section{Study period and location}

The study was conducted from December 2018 to January 2020 at the Faculty of Medicine, Universidad
Nacional Mayor de San Marcos (UNMSM), Lima, Peru.

\section{Plant material}

The aerial parts of SrR were collected from Tambo district, Huancayo (Junín- Peru) at the coordinates $12^{\circ} 03^{\prime} 01^{\prime \prime} \mathrm{S}-75^{\circ} 13^{\prime} 17^{\prime \prime} \mathrm{W}$ at 3260 m.a.s.l. in April 2018. A voucher specimen is kept in the Herbarium of the Universidad Nacional Mayor de San Marcos, Peru (Id. 059-USM-2018). The plant was recognized by Hamilton Beltran-Santiago, Biology professor and expert in Botany.

\section{Extraction procedure}

The aerial parts of SrR were dried at room temperature $\left(20^{\circ} \mathrm{C}\right)$ and then subjected to successive extractions using $96 \%$ ethanol, similar to a procedure previously [15]. The extraction of SrR was completed within $72 \mathrm{~h}$ and replicated three times. The extract obtained was concentrated using a rotary evaporator at $40^{\circ} \mathrm{C}$ and $80 \mathrm{rpm}$, and finally stored at $4^{\circ} \mathrm{C}$ in an amber flask until further use.

\section{GC-MS analysis of the volatile components of S. rhizomatus}

The analysis of the extract was performed in an Agilent Technologies Chromatograph $6890 \mathrm{~N}$ series coupled to a mass spectrometer-detector (Agilent series 5973) operated in the electronionization mode at $70 \mathrm{eV}$ and fitted with a $5 \%$ diphenyl and $95 \%$ dimethylpolysiloxane capillary column (DB-5 MS, $30 \mathrm{~m} \times 0.25 \mathrm{~mm} \times 0.25 \mu \mathrm{m})$. Helium was used as the carrier gas $(1.00 \mathrm{~mL} / \mathrm{min}$ in the constant flow mode). The injection system was operated in split mode (40:1) at $220^{\circ} \mathrm{C}$. The $\mathrm{GC}$ oven temperature was $40^{\circ} \mathrm{C}$, which was kept for $3 \mathrm{~min}$, then increased to $270^{\circ} \mathrm{C}$ with a gradient rate of $8^{\circ} \mathrm{C} / \mathrm{min}$. The ion source temperature was $250^{\circ} \mathrm{C}$. One microliter of a solution of the extract diluted in $\mathrm{CH}_{2} \mathrm{Cl}_{2}(1: 100, \mathrm{v} / \mathrm{v})$ was injected into the apparatus. The extract components were identified through a computer search using the Wiley Registry of Mass Spectral Data (6 $6^{\text {th }}$ edition), and through comparison of the calculated linear retention indices with data from the literature NIST.

Quantitative data were obtained from peak areas using a flame ionization detector [16]. The percentage composition of the extract was determined based on the correlation of GC peak areas to the total chromatogram without applying any correction factor [17].

In vitro antioxidant activity against the DPPH radical

The in vitro antioxidant activity of the ethanol extract was evaluated using the method of Herrera et al. [18]. A methanol solution containing DPPH was used at a concentration of $20 \mu \mathrm{g} / \mathrm{mL}$, and the extract was used at concentrations of $200,100,50$, and $10 \mu \mathrm{g} / \mathrm{mL}$ in methanol [18].

The initial absorbance was established at $0.6 \pm 0.05(100 \%$ of free radicals; $517 \mathrm{~nm})$.

Scavenging activity $(\%)=[(\mathrm{A} 0-\mathrm{A} 1) / \mathrm{A} 0] \times 100$ 
Where A0 is the absorbance of the control reaction and $\mathrm{A} 1$ is the absorbance in the presence of the sample, corrected by the absorbance of the sample itself (blank).

\section{Experimental animals}

Female albino Holtzman rats with an average weight of $160 \pm 20 \mathrm{~g}$ and $\mathrm{BALB} / \mathrm{c}$ female mice weighing 25-30 g were purchased from the National Institute of Health (INS) of Peru and conditioned for 7 days in large, ventilated cages with standard pelletized food and purified water ad libitum. The study was carried out in the facilities of the Faculty of Human Medicine of the UNMSM. The rats were kept in a $12 \mathrm{~h}: 12 \mathrm{~h}$ light:dark cycle at a temperature of $21^{\circ} \mathrm{C} \pm 2^{\circ} \mathrm{C}$.

\section{Evaluation of the antitumor effect of the extract on} DMBA-induced BC in female rats

Experimental cancer induction in female rats

The evaluation of BC induced in female's rats was performed according to the method of Wang and Shang [19]. A carcinogenic chemical termed DMBA diluted in olive oil was administered at a single dose of $80 \mathrm{mg} / \mathrm{kg}$ body weight (BW) through oral administration. A total of 30 rats were randomly assigned into five groups ( $\mathrm{n}=6$ per group). Group I received physiological saline (control); Group II received DMBA; and Groups III, IV, and V received, in addition to DMBA, SrR on a daily basis at doses of 10,100 , and $200 \mathrm{mg} / \mathrm{kg} \mathrm{BW}$, respectively. The treatment lasted 14 weeks. During the evaluation, the time to the appearance of the mammary tumors (latency) was controlled by palpations in the mammary zone, and the BW of the rats was recorded weekly. At the end of the experiment, the animals were sacrificed by pentobarbital overdose.

All tumors were counted in each rat, and then removed to determine their volume and histopathological analysis. The cumulative tumor volume was calculated by the formula:

$$
\mathrm{V}=\frac{1}{2}\left[\frac{4}{3} \text { ð.a.b.c }\right]
$$

Where: $V=$ volume; $a=$ width; $b=$ length; $\mathrm{c}=$ height.

\section{Histological analysis}

After the sacrifice of the rats, the mammary tumors were removed and washed with physiological serum. The total number of tumors and the cumulative tumor volume $\left(\mathrm{cm}^{3}\right)$ was determined [19]. For the histopathological study, $0.5 \times 1.0 \mathrm{~cm}$-thick sections were prepared and fixed in $10 \%$ neutral formalin; moreover, and microtome sections with a thickness of $3 \mu \mathrm{m}$ were obtained. Finally, the sections were stained with hematoxylin and eosin (H\&E) for evaluation of necrosis, mitosis (mild, moderate, and pronounced), and infiltration using an optical microscope (Olympus BX51, Tokyo, Japan).

\section{Acute toxicity in mice}

The acute single-dose toxicity of SrR was assessed according to the 423 guidelines given by the
OECD. Three BALB/c female mice were used in each step. The dose level that was used as the starting dose was $300 \mathrm{mg} / \mathrm{kg} \mathrm{BW}$. One group was used as the negative control, which was administered $2 \mathrm{~mL} / 100 \mathrm{~g} \mathrm{BW}$ of $3 \%$ polysorbate 80 orally, while the other treatment groups received SrR orally at different doses: 300 and $2000 \mathrm{mg} / \mathrm{kg}$, respectively. At the beginning of the experiment, the weight of each animal was determined and mice were observed for $4 \mathrm{~h}$ (to check for toxicity signs after the treatment); subsequently, the mice were observed once a day for a period of 14 days, during which changes in behavior and other parameters, such as BW, food intake, motor activity, tremor, diarrhea, eye and skin colors, and death, were monitored [20].

Absorption, distribution, metabolism, excretion (ADME) and molecular property prediction of the main volatile phytochemicals of SrR

A theoretical in silico ADME prediction study, under Lipinski's "Rule of five" [21], was employed based on the main phytochemicals with high values (expressed as percentages), that is, Hop-22(29)-en$3 \beta$-ol, 1,4-benzenediol mono-tetradecyl ether, and cis-totarol, methyl ether. Lipinski's parameters were calculated using a free web tool, Swiss ADME [22]. Other parameters, such as topological polar surface area, water solubility, CYP2D6, CYP2D9, P-glycoprotein inhibition, and phospholipidosis induction, were determined.

\section{Statistical analysis}

The study parameters, such as total number of tumors and cumulative tumor volume $\left(\mathrm{cm}^{3}\right)$, were expressed as absolute values, as well as averages and standard deviations. The incidence of tumors and histopathological findings, such as necrosis, mitosis, and inflammation, was expressed as percentages. The data were analyzed to determine the homogeneity of the variance using the Levene test and to assess normality using the Wilk-Shapiro statistics. A one-way analysis of variance was performed, followed by the Tukey multiple comparison method, to compare the average value of the different groups. Fisher's exact test was used to assess differences in the incidence of tumors, necrosis, mitosis, and inflammation. Significance was set at $\mathrm{p}<0.05$ in all cases. Data were analyzed using SPSS v. 21.

\section{Results}

\section{Phytochemical analysis}

The GC-MS analysis revealed the presence of cis-totarol methyl ether (3.93\%), 1,4-benzenediol, mono-tetradecylether (44.18\%), and Hop-22(29)-en$3 \beta$-ol $(4.24 \%)$ as the major volatile components of the aerial parts of SrR (Figure-1). As shown in Table-1, several components were not identified that represented about $35 \%$ of the total components of the extract.

\section{Antioxidant activity of ethanol extract of SrR, as assessed using the DPPH method}

Table-2 shows the antioxidant activity of the ethanol extract of $\mathrm{SrR}$, as assessed using the $\mathrm{DPPH}$ 
Table-1: Compounds identified in ethanol extract of Senecio rhizomatus Rusby aerial parts.

\begin{tabular}{|c|c|c|c|c|}
\hline $\mathbf{n}$ & Compounds & IR $\mathbf{R}^{\exp }$ & IR $^{\text {ref }}$ & Percentage \\
\hline 1 & n-Hexadecanoic acid & 1958 & 1957 & 0.68 \\
\hline 2 & Hexadecanoic acid, ethylester & 1992 & 1991 & 0.47 \\
\hline 3 & Phytol & 2109 & 2122 & 0.51 \\
\hline 4 & $\begin{array}{l}9,12,15 \text {-Octadecatrienoic acid, methyl ester, } \\
(Z, Z, Z)-\end{array}$ & 2135 & 2098 & 0.64 \\
\hline 5 & Unidentified & 2148 & - & 0.34 \\
\hline 6 & Linoleic acid ethyl ester & 2160 & 2155 & 0.57 \\
\hline 7 & $\begin{array}{l}9,12,15 \text {-Octadecatrienoic acid, ethyl ester, } \\
(Z, Z, Z)-\end{array}$ & 2166 & 2153 & 1.01 \\
\hline 8 & Unidentified & 2193 & - & 1.69 \\
\hline 9 & Jasmoline I & 2208 & 2345 & 0.26 \\
\hline 10 & cis-Totarol, methyl ether & 2232 & 2223 & 3.93 \\
\hline 11 & $5,6,7,8$-Tetrahydrothieno[2,3-b] quinoline & 2329 & - & 1.23 \\
\hline 12 & 2,4,7-Pteridinetriamine, 6-methyl- & 2395 & 2255 & 0.66 \\
\hline 13 & Pyrethrin I & 2417 & 2335 & 1.34 \\
\hline 14 & 1,4-Benzenediol, mono-tetradecyl ether & 2439 & 2382 & 44.18 \\
\hline 15 & Unidentified & 2467 & - & 0.98 \\
\hline 16 & Phenanthrene, 9-dodecyltetradecahydro- & 2489 & 2638 & 0.42 \\
\hline 17 & Unidentified & 2503 & - & 0.87 \\
\hline 18 & Acetophenone, 4'-(dodecyloxy)- & 2512 & 2312 & 1.03 \\
\hline 19 & Unidentified & 2524 & - & 19.43 \\
\hline 20 & Unidentified & 2533 & - & 9.42 \\
\hline 21 & Unidentified & 2614 & - & 0.96 \\
\hline 22 & 2,5-Furandione, 3-(dodecenyl) dihydro- & 2634 & 2159 & 0.64 \\
\hline 23 & Unidentified & 2647 & - & 4.50 \\
\hline 24 & 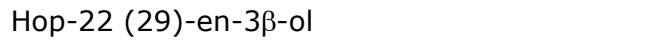 & 2668 & 2848 & 4.24 \\
\hline
\end{tabular}

LRIexp, Linear Retention Index calculated against n-alkanes C9-C24; LRIref, Linear Retention Index obtained from the literature NIST

Table-2: Antioxidant activity of the ethanolic extract of Senecio rhizomatus Rusby against DPPH radical.

\begin{tabular}{lccccc}
\hline Samples & Median value $(\mathbf{n = 3})$ & Standard error & \multicolumn{2}{c}{ Confidence interval 95\% } & \multirow{2}{*}{ Percentage } \\
\cline { 3 - 5 } & & & Lower limit & Upper limit & \\
\hline DPPH & 0.80 & 0.03 & 0.73 & 0.86 & 0.00 \\
SrR 200 & 0.12 & 0.01 & 0.08 & 0.16 & 92.50 \\
VitC 200 & 0.13 & 0.02 & 0.05 & 0.22 & 99.75 \\
\hline
\end{tabular}

SrR $200=$ Senecio rhizomatus at $200 \mathrm{ug} / \mathrm{mL}$ dissolved in DMSO; VitC $200=$ A solution of vitamin C at $200 \mathrm{ug} / \mathrm{mL}$ dissolved in distilled water, $\mathrm{DPPH}=1,1$-Diphenyl-2-picril-hidrazil

method, with a value (in percentage) that was near that of the control substance, that is, Vitamin C. A value of $100 \%$ of free radicals was taken as 0.8 at $517 \mathrm{~nm}$ using an ultraviolet-visible spectrophotometer.

\section{Evaluation of the protective effect of SrR on DMBA- induced $B C$ in female rats \\ Histopathological evaluation}

As shown in Table-3, the groups that received SrR exhibited a lower number of tumors on average, as well as a lower cumulative tumor volume compared with the DMBA group $(p<0.05)$. The incidence of tumors, which was expressed as the ratio of affected rats to the total number of animals, was $100 \%$ in the DMBA compared with the DMBA + SrR 100 and DMBA + SrR 200 groups 50\% each $(p<0.05)$. The tumor latency, which was interpreted as the number of days until the appearance of the tumors, was, on average $47.3 \pm 1.96$ days in the DMBA group, and was higher in the groups that received SrR 10, 100, and $200 \mathrm{mg} / \mathrm{kg}(56.3 \pm 1.50,53.6 \pm 1.50$, and $50.6 \pm 1.51$ days, respectively) $(\mathrm{p}<0.05)$. At the histopathological level, the groups treated with SrR showed $0 \%-16.67 \%$ of necrosis, as well as light mitosis $(100.00 \%)$, unlike the DMBA group, which exhibited necrosis in $66.67 \%$ and moderate mitosis in $100.00 \%$ of the animals.

The sections stained with H\&E showed a normal structure in the negative control group. The DMBA group presented infiltrating carcinoma with extensive tumor necrosis. In contrast, solid infiltrating carcinoma with areas of necrosis was observed in the DMBA + SrR 10 group and solid infiltrating carcinoma with cribriform areas was detected in the DMBA + SrR 100 and DMBA + SrR 200 groups (Figure-2).

\section{BW variations in animals treated with SrR}

The BW of the female rats was controlled every week. A significant decrease in BW gain was observed in the DMBA group $(\mathrm{p}<0.05)$, starting at the $8^{\text {th }}$ week of treatment; the DMBA + SrR $100 \mathrm{mg} / \mathrm{kg} / \mathrm{day}$; and $\mathrm{DMBA}+\mathrm{SrR} 200 \mathrm{mg} / \mathrm{kg} /$ day groups exhibited weight gain until the end of the evaluation (Figure-3). 


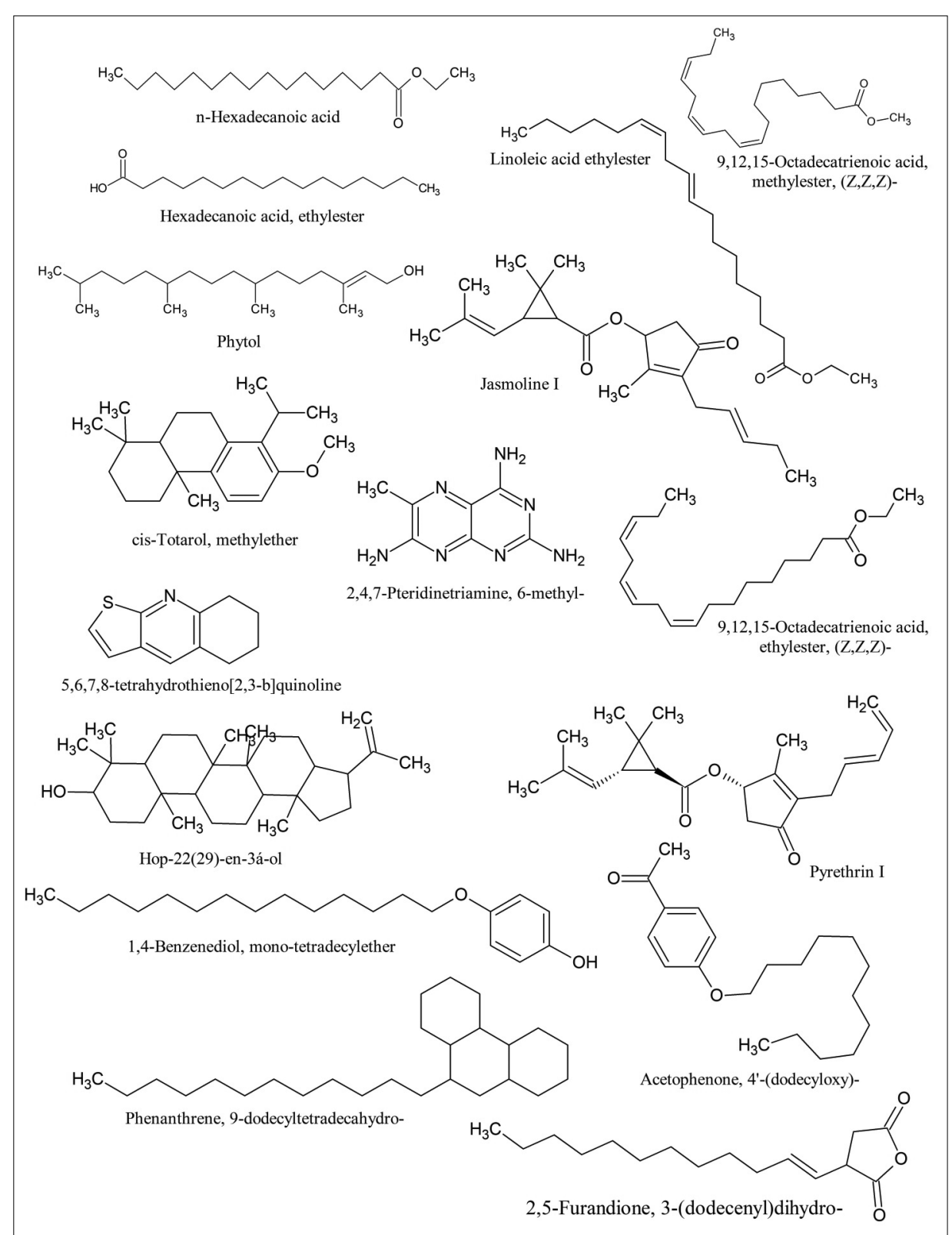

Figure-1: Main phytochemicals identified in the ethanol extract of Senecio rhizomatus Rusby by Gas Chromatography coupled to Mass Spectrometry.

Table-3: Effect of Senecio rhizomatus Rusby (SrR) on histopathological parameters.

\begin{tabular}{|c|c|c|c|c|c|}
\hline Experimental group & Negative control & DMBA & DMBA + SrR10 & DMBA + SrR100 & DMBA + SrR200 \\
\hline Total tumors $(\mathrm{N})$ & 0 & 16 & 9 & 8 & 9 \\
\hline Tumors (mean \pm SD) & 0 & $2.67(0.51)$ & $1.5(0.54)^{\alpha}$ & $1.33(0.51)^{\alpha}$ & $1.50(0.54)^{\alpha}$ \\
\hline $\begin{array}{l}\text { Volume of the } \\
\text { tumor }(\text { mean } \pm S D)\end{array}$ & 0 & $0.59(0.02)$ & $0.73(0.03)$ & $0.34(0.02)^{\alpha}$ & $0.34(0.02)^{\alpha}$ \\
\hline $\begin{array}{l}\text { Cumulative tumor } \\
\text { volume }\left(\mathrm{cm}^{3}\right)\end{array}$ & 0 & 9.45 & 6,65 & 2,72 & 3.08 \\
\hline Rats with tumors/Total & $0 / 6$ & $6 / 6$ & $4 / 6$ & $3 / 6$ & $3 / 6$ \\
\hline Tumor incidence $(\%)$ & 0 & 100.00 & 66.67 & $50.00^{\beta}$ & $50.00^{\beta}$ \\
\hline $\begin{array}{l}\text { Latency } \\
\text { tumors (mean } \pm S D \text { ) }\end{array}$ & 0 & $47.3(1.96)$ & $56.3(1.50)^{\alpha}$ & $53.6(1.50)^{\alpha}$ & $50.6(1.51)^{\alpha}$ \\
\hline \multicolumn{6}{|l|}{ Histopathology } \\
\hline Necrosis (\%) & $0 / 6(0)$ & $4 / 6(66.67)$ & $1 / 6(16.67)$ & $0 / 6(0)^{\beta}$ & $0 / 6(0)^{\beta}$ \\
\hline Mitosis light (\%) & $0 / 6(0)$ & $0 / 6(0)$ & $6 / 6(100.00)^{\beta}$ & $6 / 6(100.00)^{\beta}$ & $6 / 6(100.00)^{\beta}$ \\
\hline Moderate mitosis (\%) & $0 / 6(0)$ & $0 / 6(100.00)$ & $0 / 6(0)^{\beta}$ & $0 / 6(0)^{\beta}$ & $0 / 6(0)^{\beta}$ \\
\hline Infiltration (\%) & $0 / 6(0)$ & $6 / 6(100.00)$ & $6 / 6(100.00)$ & $6 / 6(100.00)$ & $6 / 6(100.00)$ \\
\hline
\end{tabular}

Negative control = Physiological saline, $2 \mathrm{~mL} / \mathrm{kg} ; \mathrm{DMBA}=7,12$-Dimethylbenz [a] anthracene $20 \mathrm{mg} / \mathrm{kg} ; \mathrm{SrR} 10$, SrR 100 and SrR $200=10 \mathrm{mg} / \mathrm{kg}, 100 \mathrm{mg} / \mathrm{kg}$, and $200 \mathrm{mg} / \mathrm{kg}$ of SrR, respectively. The presence of necrosis, mitoses, and infiltration was expressed in the number of rats on the total. $\alpha=$ Tukey test $(p<0.01)$ versus DMBA. $\beta=$ Fisher's exact $(p<0.01)$ versus DMBA 


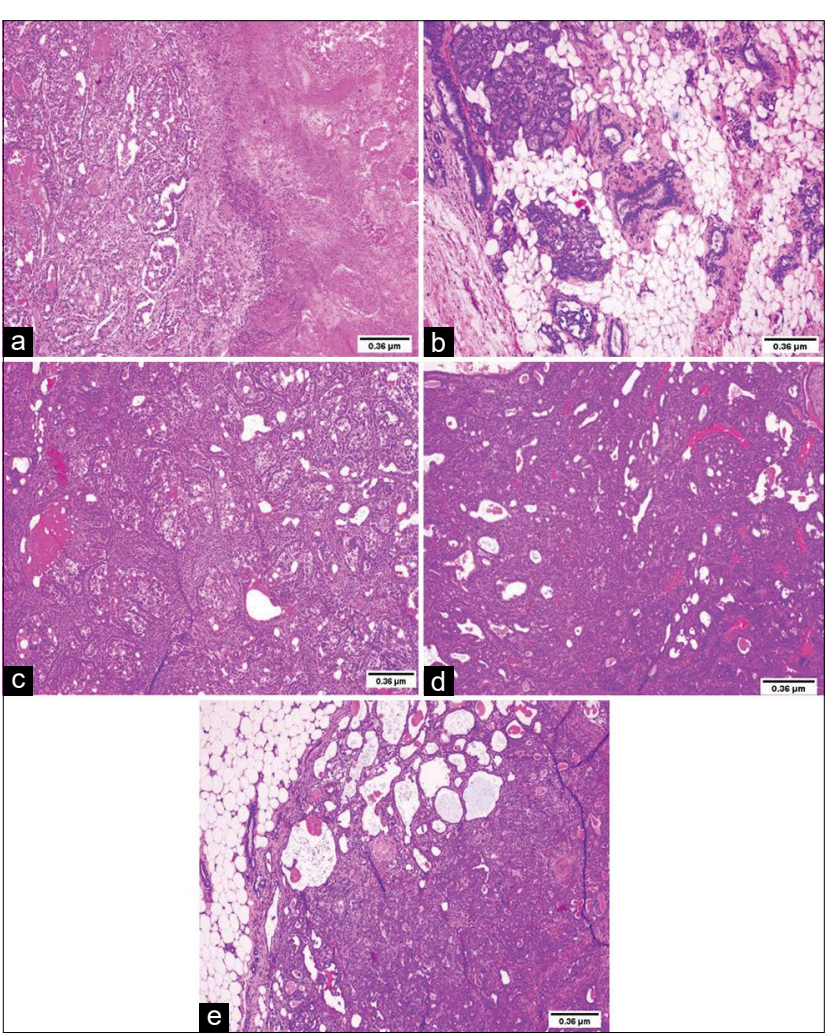

Figure-2: Staining of hematoxylin and eosin of the mammary glands of control and experimental animals (40x): (a) Negative control: Negative control group. Breast tissue within normal limits. (b) 7, 12-Dimethylbenz[a] anthracene (DMBA) Group: Infiltrating carcinoma with extensive tumor necrosis. (c) DMBA+SrR 10: Solid infiltrating carcinoma with areas of necrosis. (d) DMBA+SrR 100: Solid infiltrating carcinoma with cribriform areas. (e) DMBA+SrR 200: Solid carcinoma with cribriform areas, infiltrating adipose tissue.

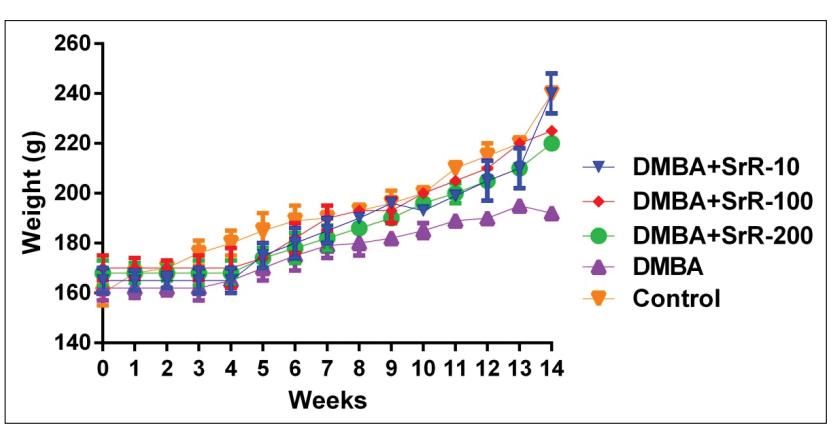

Figure-3: Weight variations of female rats during the evaluation of experimental breast cancer.

\section{Evaluation of the acute toxicity of SrR in mice accord- ing to the OECD 423 protocol}

The oral administration of SrR at doses of 300 and $2000 \mathrm{mg} / \mathrm{kg}$ did not induce death, and no signs of toxicity were observed after treatment up to $4 \mathrm{~h}$ of observation. Moreover, up to day 14, there were no changes in behavior and other parameters, such as BW, food intake, motor activity, tremor, diarrhea, and eye and skin colors.

\section{ADME and molecular property prediction}

Bioavailability is an important factor in the therapeutic effect of orally administered drugs.
The theorical predictors for the three compounds (Hop-22(29)-en-3ß-ol; 1,4-benzenediol-mono-tetradecylether, and cis-totarol, methyl ether) included by molecular flexibility, a poor intestinal absorption, a low polar surface area, poor solubility, and hydrogen-binding capacity. None of the phytochemicals passed Lipinski's "Rule of 5" (Table-4). The Lipinski rule was violated regarding the MLogP values for the three compounds, as the values were $>4.15$. Moreover, 1,4-benzenediol-mono-tetradecylether showed inhibition of CYP1A2 and CYP2C19.

\section{Discussion}

The ethanolic extract of $\mathrm{SrR}$ contained volatile components, as assessed by GC-MS, being the first SrR phytochemicals identified to date. Other reports of Senecio genera, such as $S$. scandens, revealed the presence of phenolic acids, flavonoids, saponins, lactones, terpenes, carotenoids, and volatile chemicals [23]. Phenolic compounds, specifically flavonoids, have been described as chemopreventive agents in cancer therapy; quercetin, a type of flavonol, has been reported as an anticancer substance against prostate and BCs [24]. Moreover, it exhibits antioxidant, anti-inflammatory, and antitumor properties. Quercetin induces apoptosis in BC cells by suppressing the p38MAPK pathway [25]. The biochemical mechanisms and genotoxicity of this compound should be studied further. The cytotoxic effects of $S$. graveolens and 4-hydroxy-3-(3-methyl-2-butenyl) acetophenone isolated from this plant were tested in the $\mathrm{BC}$ cell lines ZR-75-1, MCF-7, and MDA-MB-231. The anticarcinogenic activity of the whole-plant extract was stronger than that of its major component [26].

Table-1 shows that the use of ethanol as a solvent yielded a greater amount of the 1,4-benzenediol mono-tetradecyl ether chemical component isolated from SrR, which may have contributed to the protective effect $[27,28]$ because of its hydroquinone-related molecule (HQ; 1,4-benzenediol), a hydroxylated benzene metabolite with several biological activities, including antioxidant, neuroprotective, immunomodulatory, and anti-inflammatory functions. However, the anticancer activity of HQ is not well known, but has been investigated in vitro and in vivo in several cancer cells and models. HQ significantly induced the death of A431 (human squamous carcinoma), SYF (mouse embryonic fibroblasts), B16F10 (mouse melanoma), and MDA-MB-231 (human cancer) cells; showed a synergistic effect with other antitumor agents and suppressive effect on angiogenesis in fertilized chicken embryos; and prevented lung metastases from melanoma cells in mice in a dose-dependent manner without toxicity and adverse effects. HQ $(10 \mathrm{mg} / \mathrm{kg})$ prevented colon cancer induced by sodium azoxymethane/dextran sulfate administration in mice [29].

As indicated in Table-1, the ethanolic extract of SrR contains a chemical agent called totarol, which has antimicrobial, antioxidant, and antitumor effects. 
Table-4: ADME prediction of the volatile phytochemicals found in Senecio rhizomatus Rusby aerial parts.

\begin{tabular}{|c|c|c|c|}
\hline Parameters & 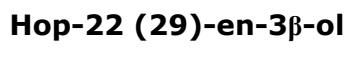 & $\begin{array}{l}\text { 1,4-Benzenediol, } \\
\text { mono-tetradecyl ether }\end{array}$ & $\begin{array}{c}\text { cis-Totarol, methyl } \\
\text { ether }\end{array}$ \\
\hline \multicolumn{4}{|l|}{ Physicochemical properties } \\
\hline Formula & $\mathrm{C}_{30} \mathrm{H}_{50} \mathrm{O}$ & $\mathrm{C}_{20} \mathrm{H}_{34} \mathrm{O}_{2}$ & $\mathrm{C}_{21} \mathrm{H}_{32} \mathrm{O}$ \\
\hline Molecular weight $(\leq 500)$ & $426.72 \mathrm{~g} / \mathrm{mol}$ & $306.48 \mathrm{~g} / \mathrm{mol}$ & $300.48 \mathrm{~g} / \mathrm{mol}$ \\
\hline Num. heavy atoms & 31 & 22 & 22 \\
\hline Num. arom. heavy atoms & 0 & 6 & 6 \\
\hline Num. rotatable bonds $(\leq 10)$ & 1 & 14 & 2 \\
\hline $\begin{array}{l}\text { Num. H-bond } \\
\text { acceptors }(\leq 10)\end{array}$ & 1 & 2 & 1 \\
\hline Num. $\mathrm{H}$-bond donors $(\leq 5)$ & 1 & 1 & 0 \\
\hline Molar refractivity & 135.14 & 97.45 & 96.10 \\
\hline TPSA $\left(\leq 140 \AA^{2}\right)$ & $20.23 \AA^{2}$ & $29.46 \AA^{2}$ & $9.23 \AA^{2}$ \\
\hline \multicolumn{4}{|l|}{ Lipophilicity } \\
\hline $\log P_{\mathrm{o} / \mathrm{w}}($ MLOGP $) \leq 4.15$ & 6.92 & 4.65 & 5.14 \\
\hline \multicolumn{4}{|l|}{ Water solubility } \\
\hline $\log S($ Ali) & -10.22 & -8.82 & -7.05 \\
\hline Class & Insoluble & Poorly soluble & Poorly soluble \\
\hline \multicolumn{4}{|l|}{ Pharmacokinetics } \\
\hline GI absorption & Low & High & Low \\
\hline BBB permeant & No & No & No \\
\hline P-gp substrate & No & No & Yes \\
\hline CYP1A2 inhibitor & No & Yes & No \\
\hline CYP2C19 inhibitor & No & Yes & Yes \\
\hline CYP2C9 inhibitor & No & No & Yes \\
\hline CYP2D6 inhibitor & No & Yes & No \\
\hline CYP3A4 inhibitor & No & No & No \\
\hline \multicolumn{4}{|l|}{ Druglikeness } \\
\hline Lipinski rule [21] & $\begin{array}{c}\text { Yes; } 1 \\
\text { violation: } \text { MLOGP>4.15 }\end{array}$ & $\begin{array}{c}\text { Yes; } 1 \\
\text { violation: } \text { MLOGP>4.15 }\end{array}$ & $\begin{array}{c}\text { Yes; } 1 \\
\text { violation: } \text { MLOGP>4.15 }\end{array}$ \\
\hline
\end{tabular}

$\mathrm{BBB}=$ Blood-brain barrier, $\mathrm{GI}=$ Gastrointestinal, $\mathrm{P}-\mathrm{gp}=$ Glycoprotein $\mathrm{P}, \mathrm{TPSA}=$ Topological polar surface area, $A D M E=$ Absorption, distribution, metabolism, excretion

Studies showed that totarol is the main component of the Kaempferia parishii rhizome extract and possibly responsible for the antitumor effect of the plant. Conversely, a phytochemical termed Hop-22(29)-en$3 \beta$-ol was found at a lower amount in SrR. A study of Cnidoscolus chayamansa isolated a chemical compound called moretenol (Hop-22(29)-en-3 $\beta$-ol) that exhibited a high percentage of anti-inflammatory activity compared with the total extract [30]. An investigation of Ficus deltoidea extracts showed its pro-apoptotic and anti-migratory effects on the human prostate cancer cell line PC3, with the hexane fraction having the major effect; oleanolic acid, moretenol, betulin, lupenone, and lupeol were isolated from this fraction and were responsible for apoptosis by activating its intrinsic pathway [31].

The protective effect of SrR against BC in rats was evidenced by the lower number of tumors, tumor volume, and tumor incidence compared with the DMBA group; moreover, the time to tumor appearance was longer. The DMBA group presented infiltrating carcinoma with a higher incidence of necrosis and moderate mitosis, in contrast with the infiltrating carcinoma with cribriform areas observed in the DMBA + SrR 100 and DMBA + SrR 200 groups. Carcinomas are the most common among the breast tumors induced experimentally by DMBA [32], reaching $100 \%$, of which approximately $50-90 \%$ are histologically malignant tumors. Tumor necrosis is rarely observed in Grade I carcinomas, in contrast to Grade III tumors, in which the disease is easily associated with some degree of infiltration; these characteristics are similar to those described for human ductal carcinoma. The micro cribriform pattern is mainly observed in Grade I carcinomas [33].

In the test of antioxidant capacity in vitro, the extract inhibited the DPPH radical at $92.5 \%$, which may be because it contains phenolic compounds with a structure resembling that of a flavonoid. Flavonoids have been shown to have free-radical-scavenging properties through electron donation and to reduce the formation of lipid peroxidation by neutralizing the chain reaction in the formation of reactive oxygen species. Our data indicate the chemopreventive potential of the SrR extract in BC, with a high therapeutic index.

Based on ADME properties predicted in silico, the three main volatile components identified by GC-MS might not be responsible for the protective effect against $\mathrm{BC}$ progression; other components, such as alkaloids or flavonoids [34], could be involved, as reported in other Senecio species [34,35]. Moreover, in medicinal plants, it is known that a set of molecules are needed to generate a pharmacological effectand not necessarily the most representative molecule. Conversely, HPLC-MS may be necessary to identify the non-volatile components of the SrR extract, which was one of the limitations of this study, together with 
the lack of determination of the biochemical mechanisms involved in the effects of the extract.

\section{Conclusion}

According to our results, the oral administration over 14 weeks of the ethanol extract of SrR had a protective effect on DMBA-induced BC in female rats, with changes observed in the histopathological study, as well as a reduction in the tumor cumulative volume and BW gain. The vitro antioxidant activity of the extract was not related with the protective effect because other biochemical parameters were not measured. Regarding the toxicity study, the extract was not toxic at the evaluated doses according to the OECD 423 guidelines, and three main phytochemicals were identified by GC/MS; however, we did not attribute the protective effects to their presence, and further studies are necessary to establish any biochemical mechanism and immunohistochemical analyses are necessary to assess BC progression.

\section{Authors' Contributions}

JLA and $\mathrm{OH}$ conceived the study designed. JLA and JPR performed the experiment. $\mathrm{OH}$ and $\mathrm{RC}$ analyzed the data. TB, JC, and $\mathrm{OH}$ drafted and revised the manuscript. All authors read and approved the final manuscript.

\section{Acknowledgments}

This study was financially supported by the Universidad Nacional Mayor de San Marcos (UNMSM), Lima, Peru, through project ${ }^{\circ}$ A 18010322. The authors would like to thank Dr. Cristian AguilarCarranza, Instituto Nacional Cardiovascular (Lima, Peru), for his help in histopathological study.

\section{Competing Interests} interests.

The authors declare that they have no competing

\section{Publisher's Note}

Veterinary World remains neutral with regard to jurisdictional claims in published institutional affiliation.

\section{References}

1. Bray, F., Ferlay, J., Soerjomataram, I., Siegel, R.L., Torre, L.A. and Jemal, A. (2018) Global cancer statistics 2018: GLOBOCAN estimates of incidence and mortality worldwide for 36 cancers in 185 countries. CA. Cancer J. Clin., 68(6): 394-424.

2. Duggan, C., Dvaladze, A.L., Tsu, V., Jeronimo, J., Constant, T.K.H., Romanoff, A., Scheel, J.R., Patel, S., Gralow, J.R. and Anderson, B.O. (2017) Resource-stratified implementation of a community-based breast cancer management programme in Peru. Lancet Oncol., 18(10): e607-e617.

3. Rojas, T.R., Bourdy, G., Ruiz, E., Cerapio, J.P., Pineau, P., Gardon, J., Doimi, F., Deparis, X., Deharo, E. and Bertani, S. (2018) Herbal medicine practices of patients with liver cancer in Peru: A comprehensive study toward integrative cancer management. Integr. Cancer Ther., 17(1): 52-64.

4. Bussmann, R.W. (2013) The globalization of traditional medicine in Northern Peru: From shamanism to molecules. Evid. Based Complement. Altern. Med., 2013:291903.

5. Guido, P.C., Ribas, A., Gaioli, M., Quattrone, F. and Macchi, A. (2015) The state of the integrative medicine in Latin America: The long road to include complementary, natural, and traditional practices in formal health systems. Eur. J. Integr. Med., 7(1): 1-10.

6. Bussmann, R.W., Malca, G., Glenn, A., Sharon, D., Nilsen, B., Parris, B., Dubose, D., Ruiz, D., Saleda, J., Martinez, M., Carillo, L., Walker, K., Kuhlman, A. and Townesmith, A. (2011) Toxicity of medicinal plants used in traditional medicine in Northern Peru. J. Ethnopharmacol., 137(1): 121-140.

7. Bussmann, R.W., Malca-García, G., Glenn, A., Sharon, D., Chait, G., Díaz, D., Pourmand, K., Jonat, B., Somogy, S., Guardado, G., Aguirre, C., Chan, R., Meyer, K., Kuhlman, A., Townesmith, A., Effio-Carbajal, J., Frías-Fernandez, F. and Benito, M. (2010) Minimum inhibitory concentrations of medicinal plants used in Northern Peru as antibacterial remedies. J. Ethnopharmacol., 132(1): 101-108.

8. Dillon, M.O. and Luebert, F. (2014) Synopsis of Plazia Ruiz and Pav. (Onoserideae, Asteraceae), including a new species from Northern Peru. PhytoKeys, 34: 1-13.

9. Ulloa, C.U., Acevedo-Rodríguez, P., Beck, S., Belgrano, M.J., Bernal, R., Berry, P.E., Brako, L., Celis, M., Davidse, G., Forzza, R.C., Robbert Gradstein, S., Hokche, O., León, B., León-Yánez, S., Magill, R.E., Neill, D.A., Nee, M., Raven, P.H., Stimmel, H., Strong, MT, Villaseñor, J.L., Zarucchi, J.L., Zuloaga, F.O. and Jørgensen, P.M. (2017) An integrated assessment of the vascular plant species of the Americas. Science, 358(6370): 1614-1617.

10. De Feo, V., Soria, E.U., Soria, R.U. and Senatore, F. (2003) Chemical composition of essential oils of Senecio nutans Sch.-Bip. (Asteraceae). Flavour Fragr. J., 18(3): 234-236.

11. Tubée, D.B.M. (2014) Three new caespitose species of Senecio (Asteraceae, Senecioneae) from South Peru. PhytoKeys, 39: 1-17.

12. Arroyo, J., Bonilla, P., Ráez, E., Barreda, A. and Huamán, O. (2010) Efecto quimioprotector de Bidens pilosa en el cáncer de mama inducido en ratas TT-Bidens pilosa chemoprotective effect on induced breast cancer in rats. An. Fac. Med., 71(3): 153-159.

13. Arroyo-Acevedo, J.L., Herrera-Calderon, O., TincoJayo, J.A., Rojas-Armas, J.P., Rauf, A., Hañari-Quispe, R., Figueroa-Salvador, L., Fernández-Guzmán, V. and YuliPosadas, R.Á. (2020) Ameliorative effect of the oral administration of Chuquiraga spinosa in a murine model of breast cancer induced with 7,12-dimethylbenz[a]anthracene (DMBA). Pharmacogn. J., 12(3): 562-568.

14. Page, R., Baneux, P., Vail, D., Duda, L., Olson, P., Anestidou, L., Dybdal, N., Golab, G., Shelton, W., Salgaller, M. and Hardy, C. (2016) Conduct, oversight, and ethical considerations of clinical trials in companion animals with cancer: Report of a workshop on best practice recommendations. J. Vet. Intern. Med., 30(2): 527-535.

15. Rojas-Armas, J.P., Arroyo-Acevedo, J.L., PalominoPacheco, M., Herrera-Calderón, O., Ortiz-Sánchez, J.M., Rojas-Armas, A., Calva, J., Castro-Luna, A. and HilarioVargas, J. (2020) The essential oil of Cymbopogon citratus stapt and carvacrol: An approach of the antitumor effect on 7,12-dimethylbenz-[ $\alpha]$-anthracene (DMBA)-induced breast cancer in female rats. Molecules, 25(14): 3284

16. van Den Dool, H. and Kratz, P. (1963) A generalization of the retention index system including linear temperature programmed gas-liquid partition chromatography. $J$. Chromatogr. A, 11: 463-471.

17. Johnsen, L.G., Skou, P.B., Khakimov, B. and Bro, R. (2017) Gas chromatography-mass spectrometry data processing made easy. J. Chromatogr. A, 1503: 57-64.

18. Herrera-Calderon, O., Arroyo-Acevedo, J.L., Rojas-Armas, J., Chumpitaz-Cerrate, V., Figueroa-Salvador, 
L., Enciso-Roca, E. and Tinco-Jayo, J.A. (2017) Phytochemical screening, total phenolic content, antioxidant and cytotoxic activity of Chromolaena laevigata on human tumor cell lines. Annu. Res. Rev. Biol., 21(1): 1-9.

19. Wang, Z. and Zhang, X. (2017) Chemopreventive activity of honokiol against 7, 12-dimethylbenz[a]anthracene-induced mammary cancer in female Sprague Dawley rats. Front. Pharmacol., 8: 320.

20. Jonsson, M., Jestoi, M., Nathanail, A.V., Kokkonen, U.M., Anttila, M., Koivisto, P., Karhunen, P. and Peltonen, K. (2013) Application of OECD guideline 423 in assessing the acute oral toxicity of moniliformin. Food Chem. Toxicol., 53: 27-32.

21. Lipinski, C.A., Lombardo, F., Dominy, B.W. and Feeney, P.J. (2012) Experimental and computational approaches to estimate solubility and permeability in drug discovery and development settings. Adv. Drug Deliv. Rev., 46(1-3): 3-26.

22. SwissADME No Title. (2020) Available from: http://www. swissadme.ch. Retrieved on 17-08-2020.

23. Wang, D., Huang, L. and Chen, S. (2013) Senecio scandens Buch. Ham.: A review on its ethnopharmacology, phytochemistry, pharmacology, and toxicity. J. Ethnopharmacol., 149(1): 1-23.

24. Iriti, M., Kubina, R., Cochis, A., Sorrentino, R., Varoni, E.M., Kabała-Dzik, A., Azzimonti, B., Dziedzic, A., Rimondini, L. and Wojtyczka, R.D. (2017) Rutin, a quercetin glycoside, restores chemosensitivity in human breast cancer cells. Phyther. Res., 31(10): 1529-1538.

25. Ranganathan, S., Halagowder, D. and Sivasithambaram, N.D. (2015) Quercetin suppresses twist to induce apoptosis in MCF-7 breast cancer cells. PLoS One, 10(10): e0141370.

26. Echiburú-Chau, C., Alfaro-Lira, S., Brown, N., Salas, C.O., Cuellar, M., Santander, J., Ogalde, J.P. and Rothhammer, F. (2014) The selective cytotoxicity elicited by phytochemical extract from Senecio graveolens (Asteraceae) on breast cancer cells is enhanced by hypoxia. Int. J. Oncol., 44(4): 1357-1364.

27. Kini, S.G., Choudhary, S. and Mubeen, M. (2012) Synthesis, docking study and anticancer activity of coumarin substituted derivatives of benzothiazole. J. Comput. Methods
Mol. Des., 25(6): 873-883.

28. Bollu, R., Palem, J.D., Bantu, R., Guguloth, V., Nagarapu, L., Polepalli, S. and Jain, N. (2015) Rational design, synthesis and anti-proliferative evaluation of novel 1,4-benzoxazine-[1,2,3]triazole hybrids. Eur. J. Med. Chem., 89: $138-146$

29. Byeon, S., Yi, Y.S., Lee, J., Yang, W., Kim, J., Kim, J., Hong, S., Kim, J.H. and Cho, J. (2018) Hydroquinone exhibits in vitro and in vivo anti-cancer activity in cancer cells and mice. Int. J. Mol. Sci., 19(3): 903.

30. Pérez-González, M.Z., Gutiérrez-Rebolledo, G.A., YépezMulia, L., Rojas-Tomé, I.S., Luna-Herrera, J. and JiménezArellanes, M.A. (2017) Antiprotozoal, antimycobacterial, and anti-inflammatory evaluation of Cnidoscolus chayamansa (Mc Vaugh) extract and the isolated compounds. Biomed. Pharmacother., 89: 89-97.

31. Hanafi, M.M.M., Afzan, A., Yaakob, H., Aziz, R., Sarmidi, M.R., Wolfender, J.L. and Prieto, J.M. (2017) In vitro pro-apoptotic and anti-migratory effects of Ficus deltoidea L. plant extracts on the human prostate cancer cell lines PC3. Front. Pharmacol., 8: 895.

32. Rocha, K., Oliveira, C.N., Azevedo, Í.M., Macedo, R., \& Medeiros, A.C. (2019) Effect of Arrabidaea chica extract against chemically induced breast cancer in animal model. Acta Cir. Bras., 34(10): e201901001.

33. Rakha, E.A., Reis-Filho, J. S., Baehner, F., Dabbs, D.J., Decker, T., Eusebi, V., Fox, S. B., Ichihara, S., Jacquemier, J., Lakhani, S.R., Palacios, J., Richardson, A.L., Schnitt, S. J., Schmitt, F.C., Tan, P. H., Tse, G.M., Badve, S., and Ellis, I.O. (2010) Breast cancer prognostic classification in the molecular era: the role of histological grade. Breast Cancer Res., 12(4): 207.

34. Ruiz-Vásquez, L., Reina, M., López-Rodríguez, M., Giménez, C., Cabrera, R., Cuadra, P., Fajardo, V. and González-Coloma, A. (2015) Sesquiterpenes, flavonoids, shikimic acid derivatives and pyrrolizidine alkaloids from Senecio kingii Hook. Phytochemistry, 117: 245-253.

35. El-Shazly, A. (2002) Pyrrolizidine alkaloid profiles of some Senecio species from Egypt. Z. Naturforsch. C J Biosci., 57(5-6): 429-433.

$* * * * * * * *$ 